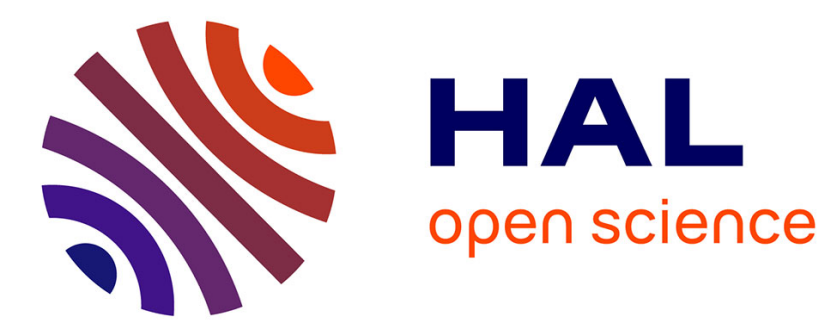

\title{
Synergic effects of activation routes of ground granulated blast-furnace slag (GGBS) used in the precast industry
}

\author{
Martin Cyr, Cédric Patapy
}

\section{To cite this version:}

Martin Cyr, Cédric Patapy. Synergic effects of activation routes of ground granulated blast-furnace slag (GGBS) used in the precast industry. 2016. hal-01344929

\author{
HAL Id: hal-01344929 \\ https://hal.science/hal-01344929
}

Preprint submitted on 12 Jul 2016

HAL is a multi-disciplinary open access archive for the deposit and dissemination of scientific research documents, whether they are published or not. The documents may come from teaching and research institutions in France or abroad, or from public or private research centers.
L'archive ouverte pluridisciplinaire HAL, est destinée au dépôt et à la diffusion de documents scientifiques de niveau recherche, publiés ou non, émanant des établissements d'enseignement et de recherche français ou étrangers, des laboratoires publics ou privés. 


\title{
Synergic effects of activation routes of ground granulated blast- furnace slag (GGBS) used in the precast industry
}

\author{
Martin CYR ${ }^{1}$, Cédric PATAPY ${ }^{2}$ \\ ${ }^{1,2}$ LMDC, Université de Toulouse, INSA, UPS, France \\ ${ }^{1}$ Martin.Cyrainsa-toulouse.fr, ${ }^{2}$ Cedric.Patapyainsa-toulouse.fr
}

\begin{abstract}
Ground granulated blast-furnace slag (GGBS) is a common by-product used for decades in the cement and concrete industry, and having beneficial effects on environmental properties and durability of concretes. However, GGBS reacts less rapidly than cement and the short-term compressive strength of GGBS-concretes are usually lower than the ones of Portland cement concretes. The aim of this paper is to test the efficiency and evaluate the synergic effect of combining different activation routes (fineness of Portland cement and GGBS, use of chemical activation, and application of thermal cycles) on shortterm compressive strength of GGBS-Portland cementbased materials. Results showed that the simultaneous use of all activation routes allowed blended cement with GGBS to achieve almost the same initial mechanical characteristics than Portland cement.
\end{abstract}

Keywords - ground granulated blast-furnace slag, activation, temperature, fineness

\section{INTRODUCTION}

Ground granulated blast-furnace slag (GGBS) is a common supplementary cementing material (SCM) used for decades in the cement and concrete industry. GGBS is a by-product of the steel industry, rapidly quenched with water and ground to a fineness similar to that of a Portland cement. The main components of GGBS are $\mathrm{CaO}(30-50 \%), \mathrm{SiO}_{2}(28-38 \%)$, $\mathrm{Al}_{2} \mathrm{O}_{3}$ (8-24\%), and $\mathrm{MgO}$ (1-18\%). GGBS has been recognized to have beneficial effects on environmental properties (lower $\mathrm{CO}_{2}$ production than Portland cement) and durability of concretes. Examples of durability improvement of GGBS-based concretes are numerous and can be found easily in the literature [1-3].

However, GGBS reacts less rapidly than cement and the shortterm compressive strength of GGBS-concretes are usually lower than the ones of Portland cement concretes. This situation could be a problem in domain such as the precast industry, where the short-term strength (e.g. between $6 \mathrm{~h}$ and $24 \mathrm{~h}$ ) must be high enough to maintain the rate of production of concrete elements.

On the one hand, solutions exist to improve the short-term strength of GGBS concrete. They are based on mainly three approaches, most of the time used separately: increase the fineness of the GGBS, increase the temperature of curing by applying thermal cycles to the concrete, or use chemical activators to enhance the reactivity of the GGBS. On the other hand, it is well known that the increase of the cement fineness generally improves its reactivity, especially at short term.

The combination of all of these methods is not often found in the literature, but it could represent a real opportunity to counteract the limited reactivity of GGBS at young ages by exploiting the synergy between the different activation routes available. The use of higher amount of GGBS could thus improve the long term durability of the concretes, without the inconvenient of the lack of performance at very short term. The precast industry is well adapted to the combination of all these activation routes, especially because of the possibility to increase the temperature of concrete curing.

The aim of this paper is to test the efficiency and evaluate the synergic effect of combining different activation routes (fineness of Portland cement and GGBS, use of chemical activation, and application of thermal cycles) on short-term compressive strength of GGBS-Portland cement-based materials.

\section{MATERIALS and METHODS}

The Portland cement was a CEM I 52.5 N CE CP2 NF as specified in European Standard NF EN 197-1 [4]. Its chemical composition is given in Table I and its original fineness was $4000 \mathrm{~cm}^{2} / \mathrm{g}$ (Blaine specific surface). A highly amorphous industrial GGBS (chemical analysis in Table I) was used at two finenesses: 4300 and $6800 \mathrm{~cm}^{2} / \mathrm{g}$. The aggregate used in mortar production was a normalized quartz sand conformed to NF EN 196-1 with particle size ranging between 0 and $2 \mathrm{~mm}$ [5]. The sodium sulfate used for the activation of the systems was from analytical grade.

The experimental program was carried out on mortars prepared according to NF EN 196-1 [5]. The mass of binder (cement or cement+GGBS) was kept constant at $450 \mathrm{~g}$. Granular-to-sand ratio and water-to-binder ratio were set at 3 and 0.50 , respectively. A reference mortar composed of $100 \%$ of Portland cement was prepared and cured at $40^{\circ} \mathrm{C}$ and $60^{\circ} \mathrm{C}$ for $6 \mathrm{~h}$. Sixteen mortars with GGBS were cast to evaluate the effect of the following parameters (illustrated in Fig. 1): 
- $\quad$ GGBS content: $50 \%$ and $70 \%$

- GGBS fineness: $4300 \mathrm{~cm}^{2} / \mathrm{g}$ and $6800 \mathrm{~cm}^{2} / \mathrm{g}$, two industrial grades available

- cement fineness: $4000 \mathrm{~cm}^{2} / \mathrm{g}$ and $7800 \mathrm{~cm}^{2} / \mathrm{g}$, the last one being obtained after a grinding of $10 \mathrm{~min}$ in a laboratory grinder.

Formulation Cement fineness GGBS fineness
- temperature of curing: $40^{\circ} \mathrm{C}$ and $60^{\circ} \mathrm{C}$ in climate chambers

- chemical activation: $0.8 \% \mathrm{Na}_{2} \mathrm{SO}_{4}$

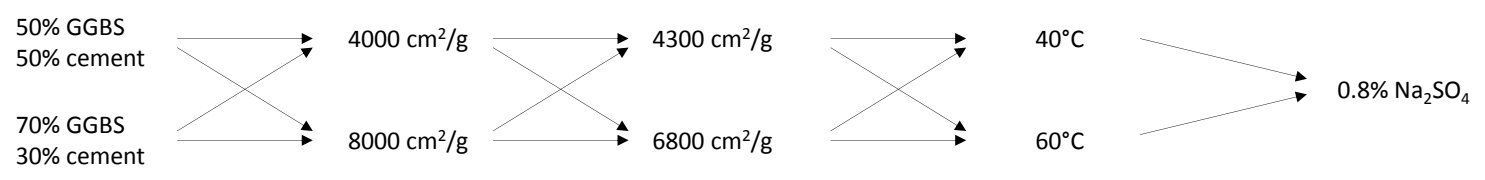

Fig. 1 Schematic representation of the 16 mortar mixtures containing GGBS

The samples were cast in $4 \times 4 \times 16 \mathrm{~cm}$ polystyrene molds, sealed in plastic bags and allowed to harden at two different temperatures: $40^{\circ} \mathrm{C}$ for $6 \mathrm{~h}$ or $60^{\circ} \mathrm{C}$ for $6 \mathrm{~h}$ (compressive strength test 1 ), followed by a cure at $20^{\circ} \mathrm{C}$ until the age of test (compressive strength test 2 ). The compressive strength results were the mean of three values.

TABLE I

PROPERTIES OF CEM I AND GGBS

\begin{tabular}{|l|c|c|}
\hline Components & CEM I & GGBS \\
\hline $\mathrm{CaO}$ & 67.41 & 41.35 \\
\hline $\mathrm{SiO}_{2}$ & 22.84 & 36.85 \\
\hline $\mathrm{Al}_{2} \mathrm{O}_{3}$ & 2.70 & 11.44 \\
\hline $\mathrm{Fe}_{2} \mathrm{O}_{3}$ & 1.84 & 0.10 \\
\hline $\mathrm{SO}_{3}$ & 2.23 & 1.93 \\
\hline $\mathrm{Na}_{2} \mathrm{O}$ & 0.14 & 0.34 \\
\hline $\mathrm{K}_{2} \mathrm{O}$ & 0.23 & 0.44 \\
\hline $\mathrm{Loss}_{\text {on ignition }(\mathrm{LOI})}$ & 1.72 & - \\
\hline Specific gravity, g/cm & \\
\hline Mass-median-diameter (D50), $\square \mathrm{m}$ & 3.13 & 2.91 \\
\hline Blaine Surface area (m & 12.6 & 12.8 \\
\hline
\end{tabular}

\section{COMPRESSIVE STRENGTH RESULTS}

Fig. 2 presents the compressive strength results at $6 \mathrm{~h}$ and $24 \mathrm{~h}$ of all mortar mixtures. For the same mixtures, Fig. 3 gives the strength activity index, defined as the ratio of compressive strength of GGBS mortar and reference mortar. Four activations routes were investigated: cement fineness, GGBS fineness, chemical activation (only at one level) and increase in the curing temperature.

It can be seen that some activation routes were better than others to improve the strength of GGBS-Portland cement mixtures. Individual activation route cannot alone allow the GGBS mixture to challenge the Portland cement. The only combination which led to the better results was the increase in the temperature to $60^{\circ} \mathrm{C}$, with fineness of cement and GGBS at their maximum levels.

Several observations can be made:
- When the curing temperature was set at $40^{\circ}$ during $6 \mathrm{~h}$ (followed by a cure at $20^{\circ} \mathrm{C}$ ), no combination of activation routes allowed us to reach, neither at $6 \mathrm{~h}$ nor $24 \mathrm{~h}$, the reference mortar composed of commercial CEM I. The better result at this curing temperature (SAI of 0.74) was obtained after $24 \mathrm{~h}$ for the mortar mixture with the finest cement and GGBS (8000 and $6800 \mathrm{~cm}^{2} / \mathrm{g}$, respectively).

- The curing temperature of $60^{\circ} \mathrm{C}$ during $6 \mathrm{~h}$ led to much better results, as it was possible to reach or get close to the reference at $6 \mathrm{~h}$ and $24 \mathrm{~h}$ for $50 \%$ GGBS mortars made with the finest cement and GGBS (8000 and $6800 \mathrm{~cm}^{2} / \mathrm{g}$, respectively). When $70 \%$ of GGBS was used, the strength at $6 \mathrm{~h}$ approached $90 \%$ of the reference with the same combination of cement-GGBS fineness. However, the strength activity index decreased at 24h (0.72), probably due to a blockage effect sometimes seen when the hydration is strongly activated [6].

- When the cement fineness was kept at $4000 \mathrm{~cm}^{2} / \mathrm{g}$, and by combining fine GGBS $\left(6800 \mathrm{~cm}^{2} / \mathrm{g}\right)$ and high temperature (e.g. $60^{\circ} \mathrm{C}$ ), it was possible to almost reach the reference cured at $40^{\circ} \mathrm{C}$ (for $50 \%$-GGBS mixtures at 6 and $24 \mathrm{~h}$, and $70 \%$-GGBS mixture at $6 \mathrm{~h}$ ). It means that it could be possible to avoid the cement grinding by combining high GGBS fineness and temperature of curing higher than the reference CEM I.

Fig. 4 presents the increase in strength (in \%) when a given parameter went from a minimum value to a maximum value. All the calculations were made by taking mortars 2 by 2 with only one parameter changing, all the others remaining equals. For example, when the GGBS fineness went from $4300 \mathrm{~cm}^{2} / \mathrm{g}$ to $6800 \mathrm{~cm}^{2} / \mathrm{g}$, several increases were calculated with constant values of cement content (30 or 50\%), cement fineness (4000 or $8000 \mathrm{~cm}^{2} / \mathrm{g}$ ), and curing temperature $\left(40\right.$ or $\left.60^{\circ} \mathrm{C}\right)$. Fig. 4 gives the mean increase of the values, as well as the minimum and maximum increases obtained. 
It can be seen (inside the min and max values of each parameter chosen in this study) that all parameters did not have the same effect on the increase in strength at young ages:

- The curing temperature had a huge effect on the strength at $6 \mathrm{~h}$, as passing from $40^{\circ} \mathrm{C}$ to $60^{\circ} \mathrm{C}$ led to a significant increase in strength between 90 and $300 \%$, with a mean value of $+174 \%$.

- This effect was much less important at $24 \mathrm{~h}$, the gain being at a mean value of $+38 \%$

- The effect of GGBS fineness was in the same order of magnitude at $6 \mathrm{~h}$ and $24 \mathrm{~h}$, with mean increase values between +36 and $+39 \%$ when the fineness of the GGBS went from 4300 to $6800 \mathrm{~cm}^{2} / \mathrm{g}$.

$50 \%$ GGBS
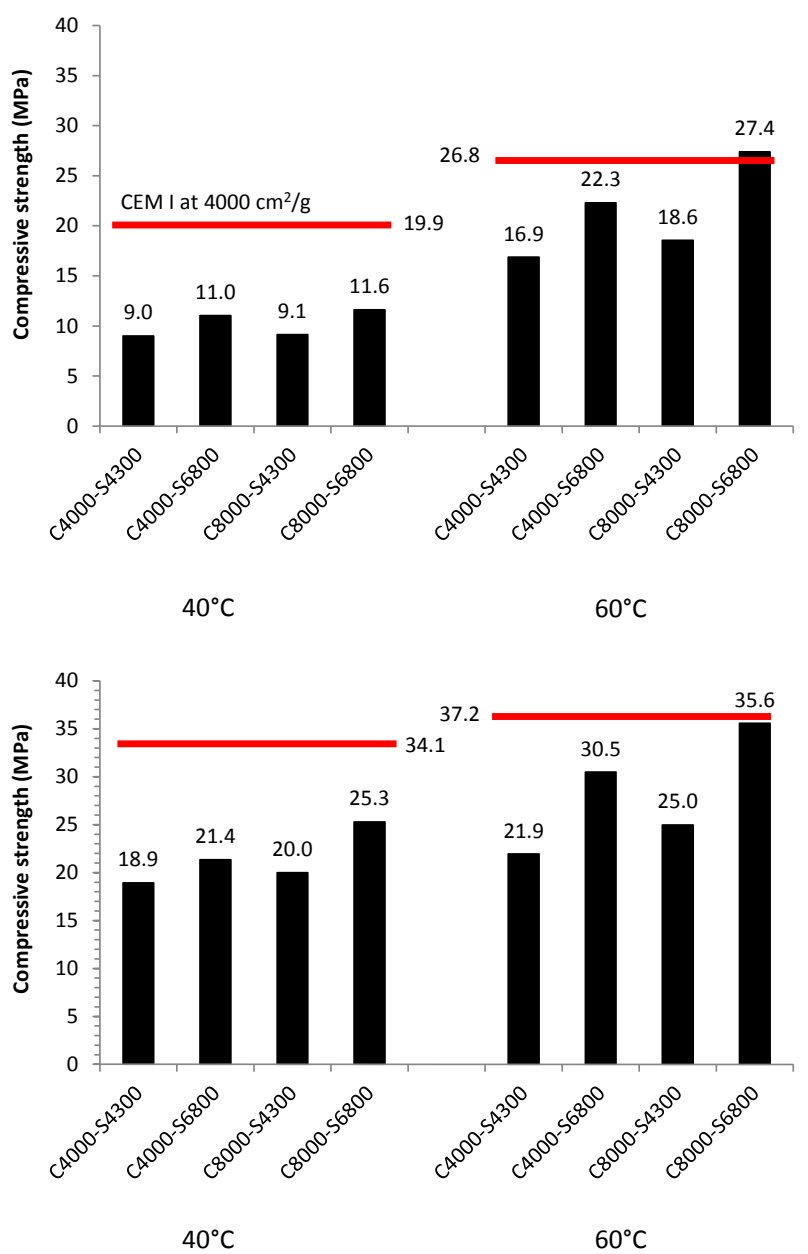

- The cement content fallowed a similar trend, meaning that $50 \%$ GGBS (i.e. $50 \%$ of cement) led logically to the better results.

- The increase of the cement fineness was the less significant parameter, as the mean increase in strength were at average values of $+13-17 \%$, although a significant effort to increase the fineness (4000 to $8000 \mathrm{~cm}^{2} / \mathrm{g}$ ). However, it should be kept in mind that the increase in cement fineness could help reaching the goal of approaching the reference mortar when it is combined to other activation routes (GGBS fineness and temperature).

\section{$70 \%$ GGBS}
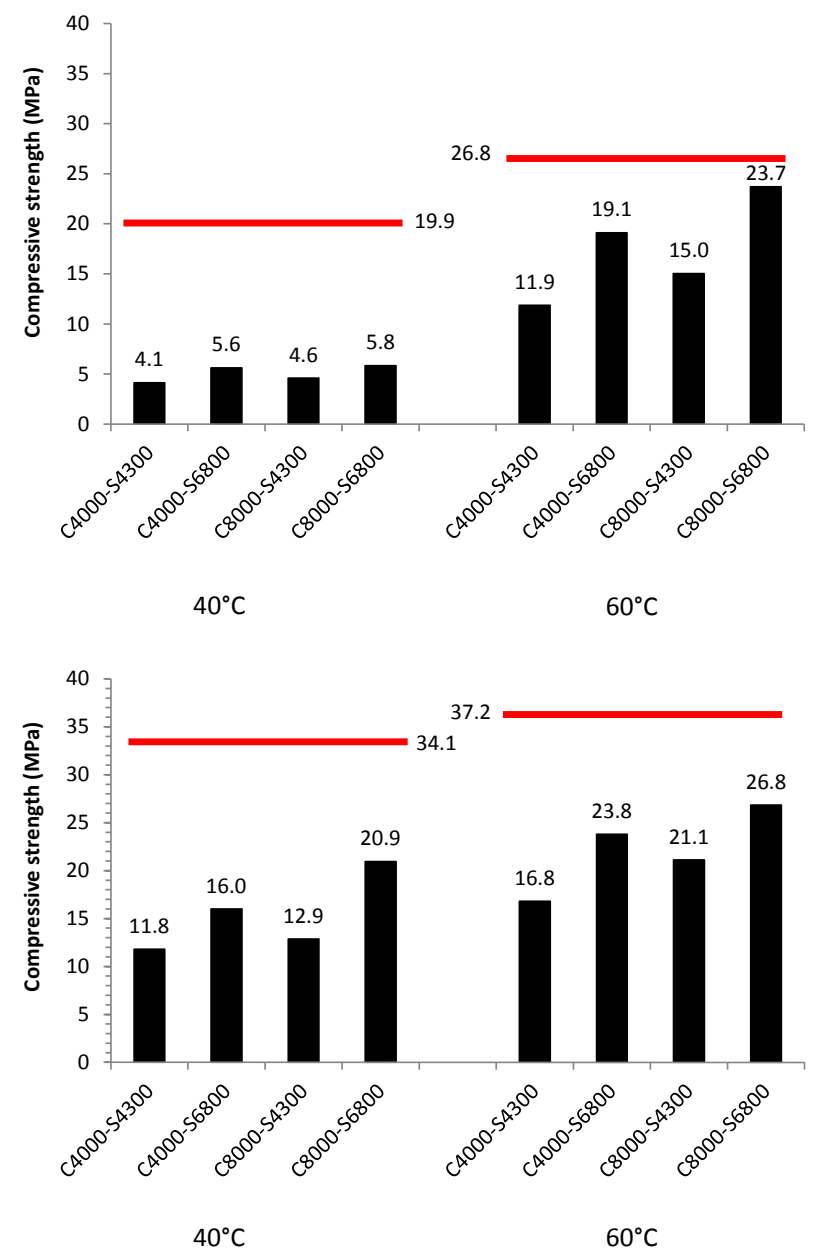

Fig. 2 Compressive strength at $6 \mathrm{~h}$ and $24 \mathrm{~h}$ of mortars cured $6 \mathrm{~h}$ at $40^{\circ} \mathrm{C}$ or $60^{\circ} \mathrm{C}$. Reference mortars contained $100 \% \mathrm{CEM} \mathrm{I}\left(4000 \mathrm{~cm}^{2} / \mathrm{g}\right)$, while GGBS mixtures (50 and $70 \%$ of fineness: 4300 or $6800 \mathrm{~cm}^{2} / \mathrm{g}$ ) were made with cement of fineness $4000 \mathrm{or} 8000 \mathrm{~cm}^{2} / \mathrm{g}$. 
$50 \%$ GGBS

$6 \mathrm{~h}$

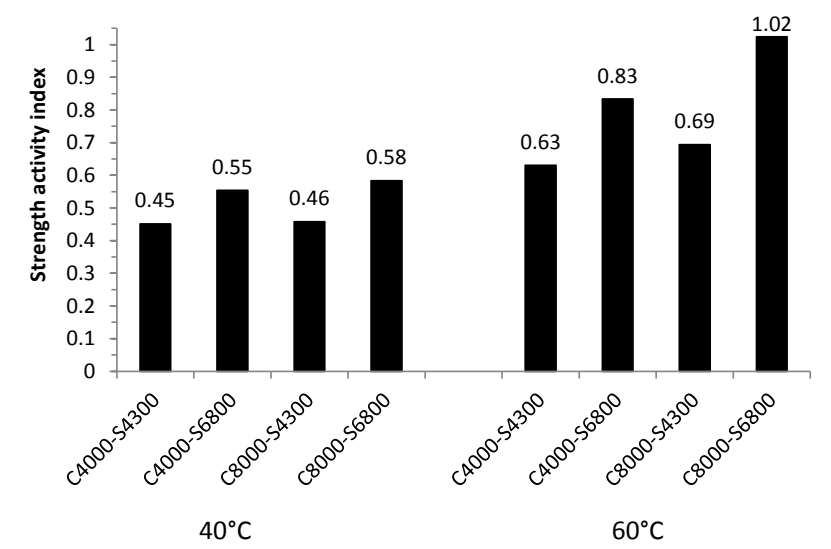

$24 h$

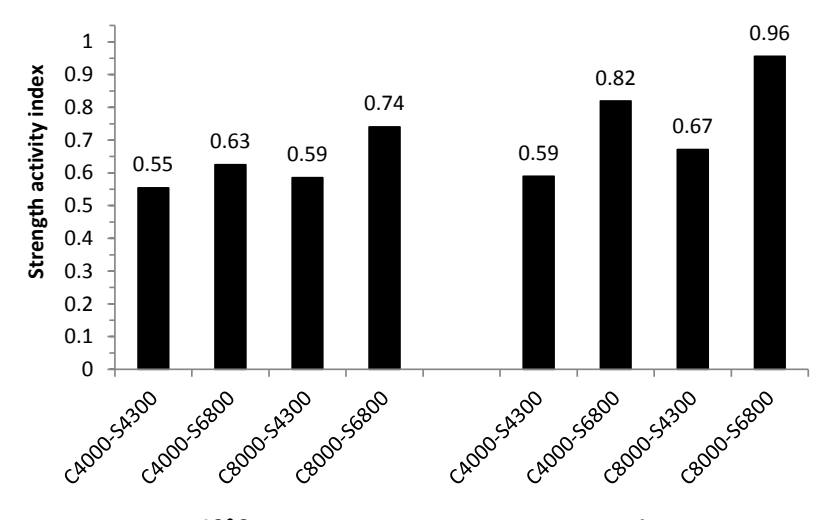

$60^{\circ} \mathrm{C}$
70\% GGBS
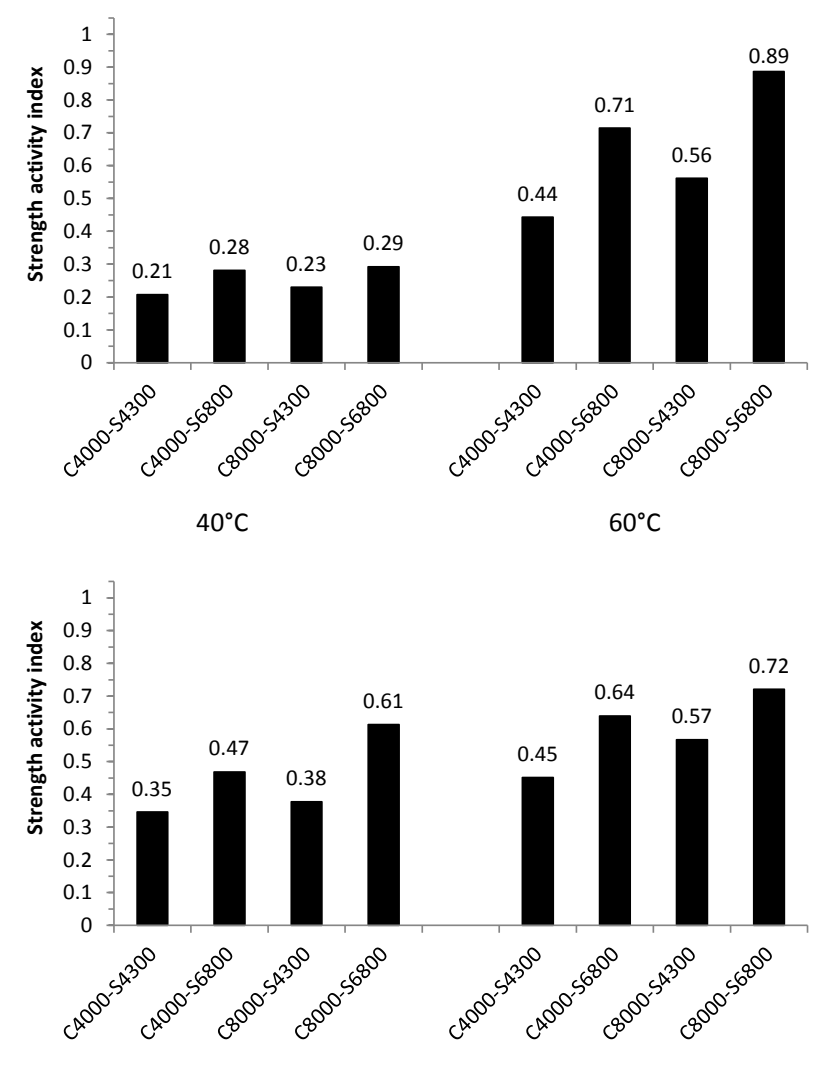

$40^{\circ} \mathrm{C}$

$60^{\circ} \mathrm{C}$

Fig. 3 Strength activity index (defined as the ratio of compressive strength of GGBS mortar and reference mortar) at $6 \mathrm{~h}$ and $24 \mathrm{~h}$ of mortars cured $6 \mathrm{~h}$ at $40^{\circ} \mathrm{C}$ or $60^{\circ} \mathrm{C}$.

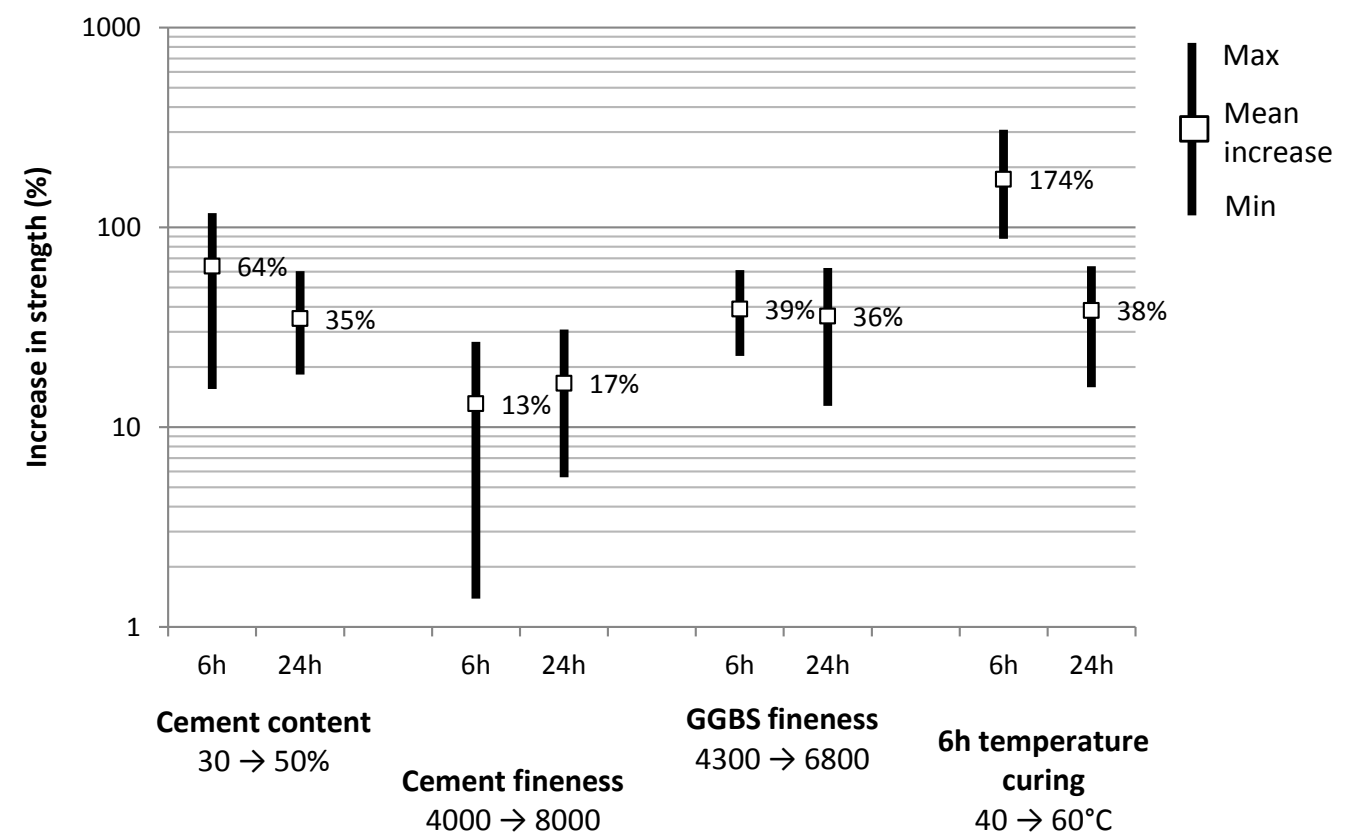

Fig. 4 Increase in strength (in \%) when a given parameter went from a minimum value to a maximum value (example: GGBS fineness from $4300 \mathrm{~cm}^{2} / \mathrm{g}$ to $6800 \mathrm{~cm}^{2} / \mathrm{g}$ ) 


\section{IV.ENERGY CONSUMPTION}

An analysis based on a simple calculation of the energy demand when GGBS is used as cement replacement is presented. The calculation is based on the energy consumed for the production of cement and GGBS, which includes the manufacturing process (e.g. heating of cement raw meal) and the final grinding of the material (clinker, GGBS). It excludes the energy for thermal treatment at 40 and $60^{\circ} \mathrm{C}$ since the comparisons are made here for mixtures cured at the same temperature.

The energy required ( $E$, in $\mathrm{kWh} / \mathrm{t}$ of binder) is given by equation 1 , as a function of the binder composition, and of the energy needed for the manufacturing process and the grinding of cement and GGBS. A calculation of the performance energy $E_{\text {performance }}$ (in $\mathrm{kWh} / \mathrm{t} / \mathrm{MPa}$ ) can also be proposed (equation 2), by dividing the required energy $E$ by the compressive strength of the mortar containing the binder under consideration. $E_{\text {performance }}$ gives the energy cost of each $\mathrm{MPa}$ of strength.

$\mathrm{E}\{$ in $\mathrm{kWh} / \mathrm{t}\}=\mathrm{C} \cdot\left(\mathrm{E}_{\text {cenent }}^{\text {process }}+\mathrm{E}_{\text {cement }}^{\text {grinding }}\right)+\mathrm{GGBS} \cdot\left(\mathrm{E}_{\mathrm{GGBS}}^{\text {process }}+\mathrm{E}_{\mathrm{GGBS}}^{\text {grinding }}\right)$

$$
\mathrm{E}_{\text {performance }}\left\{\text { in } \mathrm{kWh} / \mathrm{t} \cdot \mathrm{MPa}^{-1}\right\}=\frac{\mathrm{E}}{\text { Strength }}
$$

where

- $\mathrm{E}$ is the energy consumption (in $\mathrm{kWh}$ ) for the production of one ton of binder,
- $\mathrm{C}$ and GGBS are the proportions of cement and GGBS in the binder respectively,

- $E_{\text {cement }}^{\text {proces }}$ and $E_{\text {cement }}^{\text {grinding }}$ are the energy consumption (in $\mathrm{kWh} / \mathrm{t}$ ) of the cement manufacturing process and the finish grinding of the material, respectively,

- $\mathrm{E}_{\mathrm{GGBS}}^{\text {process }}$ and $\mathrm{E}_{\mathrm{GGBS}}^{\text {ginding }}$ are the energy consumption (in $\mathrm{kWh} / \mathrm{t}$ ) for the GGBS process and the grinding of the material, respectively,

- $\mathrm{E}_{\text {perfomance }}$ is the energy consumption for the production of one ton of binder, relative to the compressive strength of the mortar containing the binder considered,

- Strength is the compressive strength of the mortar of composition C+GGBS

The data used for the calculations were taken from the literature and are reported in Table II [7-12]. The total energy required to produce cement was evaluated to be in the range $800-1200 \mathrm{kWh}$ per ton of cement, including around $50 \mathrm{kWh} / \mathrm{t}$ for the finish grinding of the clinker. In the case of GGBS, the process energy was assumed to be $0 \mathrm{kWh} / \mathrm{t}$ (as it is a byproduct). The energy for GGBS grinding is recognized to be higher than for clinker, due to the presence of hard glass. According to various authors [11,12], 50\% more energy is necessary to reach the same fineness for GGBS as for clinker.

TABLE II

DATA USED FOR THE CALCULATION OF ENERGY CONSUMPTION

\begin{tabular}{llllll} 
& & \multicolumn{4}{c}{ Energy consumption $(\mathrm{kWh} / \mathrm{t})$} \\
\cline { 2 - 6 } $\begin{array}{llll}\text { Manufacturing } \\
\text { process }\end{array}$ & Cement & Ref & GGBS & Ref \\
Finish grinding & $\mathrm{E}_{\text {cement }}^{\text {process }}=950^{a}$ & {$[7-9]$} & From the steel plant & $\mathrm{E}_{\mathrm{GGBS}}^{\text {process }}=0$ & -- \\
\hline
\end{tabular}

a values in the literature between $800-1200 \mathrm{kWh} / \mathrm{t}$ for dry process (initial data in $\mathrm{GJ} / \mathrm{t}$, with $3.6 \mathrm{GJ}=1000 \mathrm{kWh}$ )

The results of the calculations are given in Figs. 5 and 6 for all the composition studied.

(a) Energy requirement of binder $E$, in $k W h / t$ of binder Fig. 5

When 1 ton of binder was considered, the energy consumption with GGBS was always lower than for the reference with only cement (Fig. 5). This means that 1 ton of binder with GGBS had a lower energy cost (almost proportional to the cement remaining in the system), although the grinding of GGBS required more energy than the grinding of clinker. GGBS remained less energy consuming because of the absence of energy demand of the manufacturing process.

\section{(b) Performance energy $E_{\text {performance, in }} \mathrm{kWh} / \mathrm{t} / \mathrm{MPa}-$ Fig. 6}

When the energy consumption was considered relative to the performance of mortars (for instance compressive strength at $24 \mathrm{~h}$ for mortars cured at $60^{\circ} \mathrm{C}$ ), it can be seen that:

- The use of GGBS systematically (for these conditions) involved a decrease in the energy consumption per MPa, meaning a better energetic efficiency of the system.

- The best $E_{\text {performance }}$ were obtained for fine GGBS, whatever the fineness of the cement.

- It is possible to obtain good $E_{\text {performance }}$ with up to $70 \%$ of GGBS.

This means that, from a "performance energy" point of view, it is better to use fine GGBS without considering the fineness 
of the cement. These mixtures lead to the best efficiency of the GGBS, i.e. more performance (in terms of $\mathrm{MPa}$ ) for a given energy: each MPa cost less kWh per ton of binder.

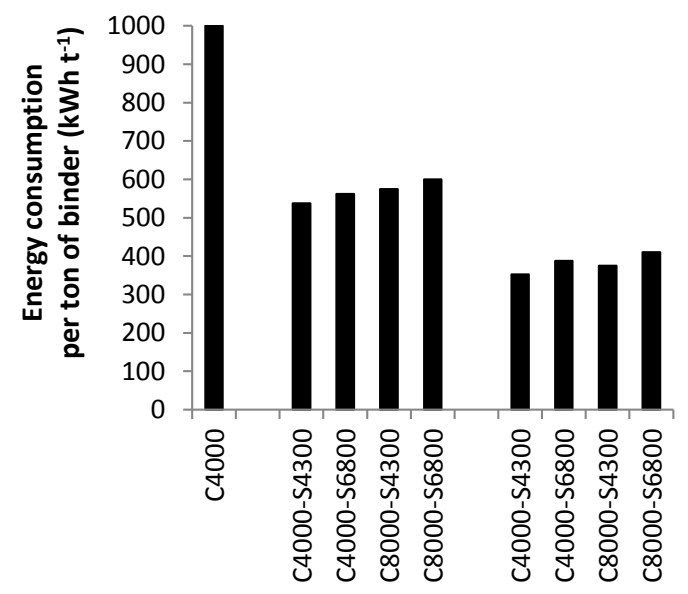

$100 \% \mathrm{C} \quad 50 \% \mathrm{GGBS} \quad 70 \% \mathrm{GGBS}$

Fig. 5 Energy consumption of mortars containing GGBS. Energy requirement of binder (E, in $\mathrm{kWh} / \mathrm{t}$ of binder).

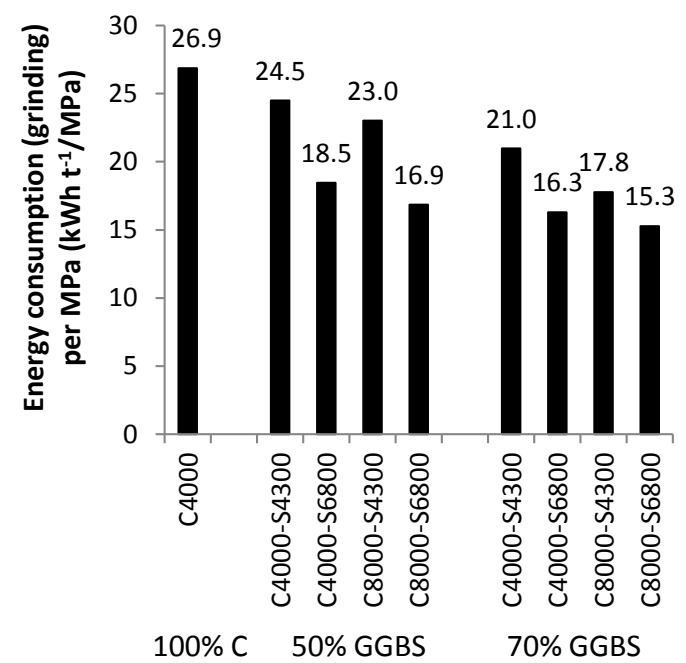

Fig. 6 Energy consumption of mortars containing GGBS. Performance energy $\left(\mathrm{E}_{\text {performance, }}\right.$, in $\mathrm{kWh} / \mathrm{t} / \mathrm{MPa}$ ) for mortars cured at $60^{\circ} \mathrm{C}$ (for $6 \mathrm{~h}$ ), then tests for compressive strength at $24 \mathrm{~h}$.

\section{Conclusion}

This paper aimed at evaluating the possibility of using GGBS blended cements in the precast industry as a challenger to Portland cement used alone. Combinations of four activation routes were tested on $50 \%$ and $70 \%$ GGBS mixtures. The following conclusions can be drawn:

- In heated systems (such as in precast industry), it is possible to challenge, in terms of compressive strength, Portland cement at $6 \mathrm{~h}$ and $24 \mathrm{~h}$, when combining chemical activation, the fineness of the GGBS, the fineness of the cement and a curing temperature of $60^{\circ} \mathrm{C}$.
- The best activation route is the temperature, followed by the fineness of the GGBS.

- The cost of each MPa (per kWh per ton of binder) is lower with fine GGBS used in replacement of the cement.

A possible perspective to optimize the GGBS mixtures would be to add fine limestone filler (LF) to improve the packing, as GGBS and LF are known to work well together.

\section{VI.REFERENCES}

[1] M. Öner, K. Erdoğdu and A. Günlü, "Effect of components fineness on strength of blast furnace slag cement”, Cem Concr Res, Vol.33, pp. 463-469, 2003.

[2] D. M. Roy, "Alkali-activated cements opportunities and challenges", Cem Concr Res, Vol.29, pp. 249-254, 1999.

[3] M. C. G. Juenger, F. Winnefeld, J. L. Provis and J. H. Ideker, "Advances in alternative cementitious binders", Cem Concr Res, Vol.41, pp. 1232-1243, 2011.

[4] EN 197-1 Cement - Part 1: Composition, specifications and conformity criteria for common cements, 2012.

[5] EN 196-1 Methods of testing cement - Part 1: Determination of strength, 2006.

[6] E. Marciano and A. F. Battagin. "The Influence of Alkali Activator on the Early Hydration and Performance of Portland Blast Furnace Slag Cement", in ICCC Gothenburg, Sweden. 1997.

[7] I.Z. Bribián, A.V. Capilla, A.A. Usón, "Life cycle assessment of building materials: Comparative analysis of energy and environmental impacts and evaluation of the eco-efficiency improvement potential", Build Environ, Vol.46, pp.1133-1140, 2011.

[8] J.A. Moya, N. Pardo and A. Mercier "The potential for improvements in energy efficiency and $\mathrm{CO}_{2}$ emissions in the EU27 cement industry and the relationship with the capital budgeting decision criteria", J Clean Prod Vol.19, pp.1207-1215,2011.

[9] C. Hosten and B. Fidan, "An industrial comparative study of cement clinker grinding systems regarding the specific energy consumption and cement properties", Powder Technol, Vol.221, pp.183-188, 2012.

[10] D. Touil, S. Belaadi and C. Frances, "Energy efficiency of cement finish grinding in a dry batch ball mill", Cem Concr Res, Vol.36, pp.416-421, 2006.

[11] R.H. Snow, T. Allen, B.J. Ennis and J.D. Litster, "Size reduction and Size Enlargement". Perry RH, Green DW (ed). Perry's Chemical Engineers' Handbook. $7^{\text {th }}$ Edition. McGraw-Hill; 1997.

[12] J.N. de la Vergne, "The Hard Rock Miner's Handbook". $3^{\text {rd }}$ Edition. McIntosh Engineering: North Bay; 2003. 